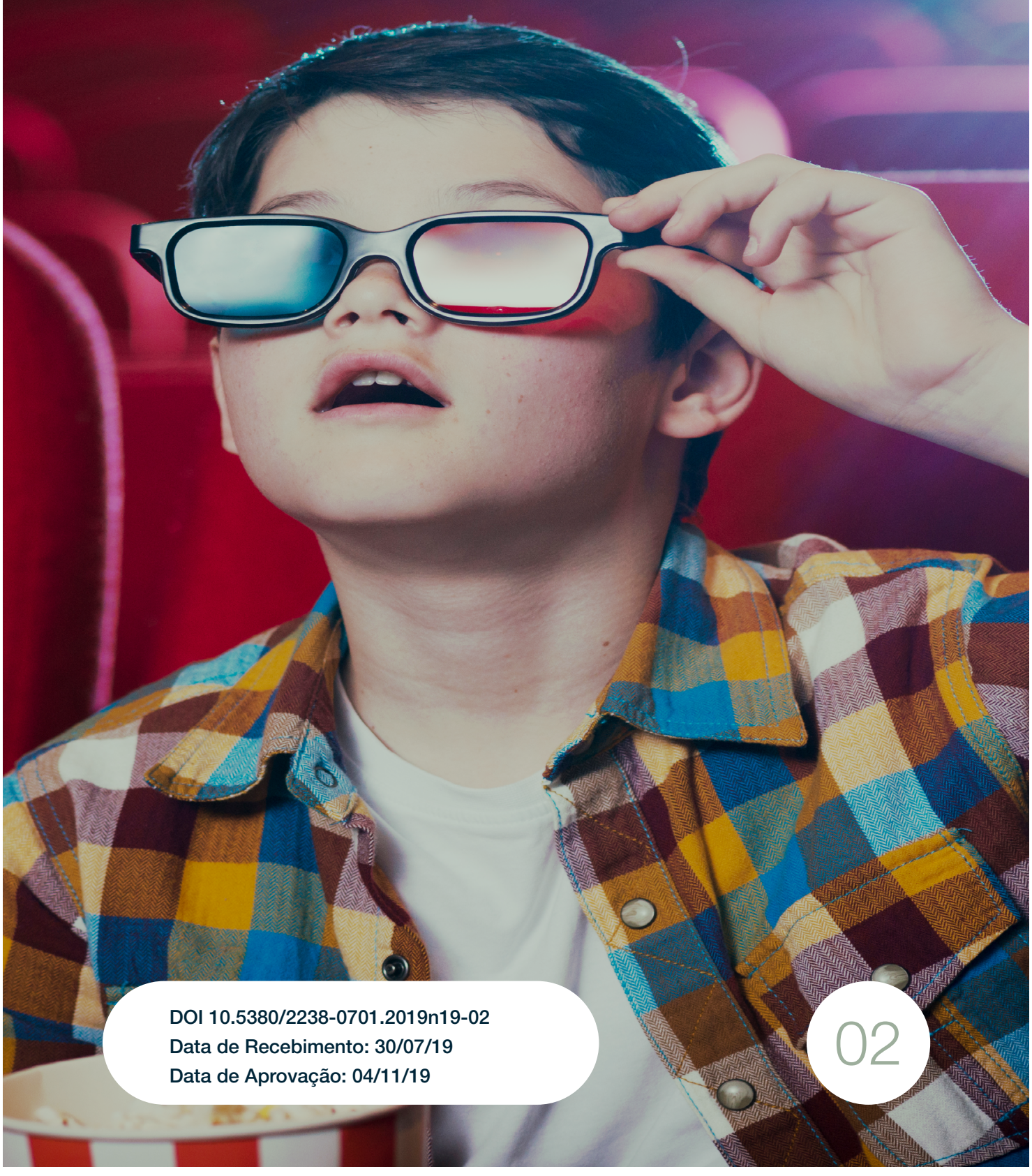


The New Myths of Speculative Fiction Cinema: How Mythical Thought is Returning in the Contemporary 


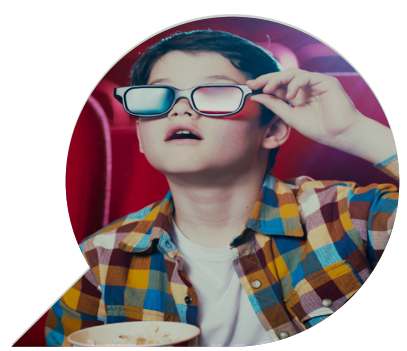

\title{
The New Myths of Speculative Fiction Cinema: How Mythical Thought is Returning in the Contemporary World
}

Os Novos Mitos do Cinema de Ficção Especulativa: Como o Pensamento Mítico Está Voltando no Mundo Contemporâneo

Los Nuevos Mitos del Cine de Ficción Especulativa: Cómo Está Volviendo el Pensamiento Mítico en el Mundo Contemporáneo

MARCO FRAGA SILVA ${ }^{1}$

\begin{abstract}
This paper argues that the decline of myth and mythical thought is reversing and that the substitute of ancient myth in modern societies - politics - has been replaced by the speculative fiction genre of cinematic storytelling. With this in mind the paper creates a link between: our species ability to tell stories and our necessity to consume them; the importance and characteristics of myth and mythical thought; the human craving for mythical stories; the contemporary speculative fiction trend worldwide in the box office; and a study of the most influential films of all time.
\end{abstract}

Keywords: Cinema; Media; Myth; Speculative Fiction; Storytelling

1 Doutorando em Arte dos Media pela Universidade Lusófona de Lisboa. E-mail: marcoffs@sapo.pt. 
Resumo: Este artigo argumenta que o declínio do mito e do pensamento mítico está sendo revertido e que o substituto do mito na sociedade moderna - a política - foi substituído pelo gênero cinematográfico da ficção especulativa. De forma a confirmar esta suposição este artigo cria uma ligação entre: a habilidade da nossa espécie em contar estórias e a nossa necessidade em consumi-las; a importância e características do mito e do pensamento mítico; a necessidade humana para consumir narrativas míticas; a hegemo do género da ficção especulativa no box office mundial; e um estudo dos filmes mais influentes de todos os tempos.

Palavras-chave: Cinema, Media, Mito, Ficção Especulativa; Storytelling

Resumen: Este artículo argumenta que el declive del mito y el pensamiento mítico se está invirtiendo y que el reemplazo del mito en la sociedad moderna - política - es ahora el género cinematográfico de la ficción especulativa. Para confirmar esta suposición, este artículo crea un vínculo entre: la capacidad de nuestra especie para contar historias y nuestra necesidad de consumirlas; la importancia y características del mito y el pensamiento mítico; la necesidad humana de consumir narraciones míticas; la hegemonía del género de ficción especulativa en la taquilla mundial; y un estudio de las películas más influyentes de todos los tiempos.

Palabras clave: Cine, Medios, Mito, Ficción Especulativa; Storytelling

\section{Introduction}

Myth and mythical though have been declining since the seventeenth century due to the rise of science and the scientific method. Claude LéviStrauss believed that mythical thought is as critical and complex as the scientific thought (2001, p. 5-6). He also said in his paper The Structural Study of Myth, published in 1955, that myth appeared to be replaced by 
politics in modern societies (1955, p. 430).

This paper argues that mythical thought decline is reversing and that new myths can be found in the field of entertainment. Speculative fiction (fantasy, horror, science fiction) has replaced myth in Western civilizations and, through its capability to create mythic and fantastic narratives, appears to be filling a gap and a craving for more mythical content by the modern Man. Joseph Campbell, in an interview with Bill Myers, published in book format in 1988, said that myths offer us the life models we need but they have to be the right ones, the appropriate ones "to the time in which you are living"; the ever-changing world cannot maintain out-ofdate morals, so, for a modern world we need new myths (1988, p. 16) and for now speculative fiction cinematic narratives seem to be carrying the torch. The world's increasing intricacy demands that the modern stories reflect this complexity. Cinema continues to introduce myths to societies and peoples in need of escaping, entertainment, and understanding the world.

This paper claims that through the apparatus of cinema, the genre of speculative fiction has replaced politics in the contemporary myth-making, or mythopoeia. Furthermore, the collapse of myth in modern societies is attenuated or even reverted by the speculative stories of fantasy, horror, and science fiction being produced and consumed; the hegemony of the speculative fiction genre in the box office worldwide is a clear sign of the consumers' hunger for these upbeat narratives filled with universal archetypes and role models.

\section{Franchised Myths}

The adaptation of myths to the cinema medium is made in two ways: adapting a myth directly or incorporating ancient myths and mythical themes into films. The Marvel Cinematic Universe (MCU) uses both methods (HAFÇI and ASLITÜRK, 2017, p. 497, 500). The modern myths of speculative fiction may lack the traditional religious context of the ancient ones but the fandom devotion to some characters and franchises is undeniable. Furthermore, the new rituals, an important facet of myth, can be found in fandom activities where fans dress up as their favorite characters as a tribute and reenact their favorite scenes. 
The new franchised myths, produced by big corporations like Walt Disney Studios, are being distinctly delivered to the public. The MCU is being fragmented through several media and platforms using the aesthetic of transmedia storytelling. Jeff Gomez, in an interview for Indiewire, shared three basic rules for transmediating a narrative: 1) the story must have positive qualities that inspire the public; 2) the production team must have adequate technical skills; 3) the relation between transmedia producers and fans must be carefully woven, validating their participation (BERNSTEIN). In the era of Cultural Convergence, fans network with ease and create contents collectively using intuitive digital tools (JENKINS, 2006, p. 2, 18, 21). The many channels on YouTube discussing the next Marvel Studios movie and the next George R. R. Martin TV series are proof of that. These digital hunter-gatherers and prosumers embrace the new mythic narratives in such a way they become gospel.

Films (and TV series) about superheroes, artificial intelligence, supernatural monsters, films about the beginning - new cosmogonies - and the end of the human species - new apocalypses - invade our screens on a regular basis. They are a part of our daily conversations and the way we perceive the world. They are the new myths.

For Lévi-Strauss all versions of a myth were equally important (2001, p. 435). Therefore, the appropriation of the Oedipus myth by Sigmund Freud and Carl Jung was legitimate. It could be argued that the appropriation of Thor and Odin and the magical realm of Asgard by Marvel Comics, and the cinematic adaptation, is now part of Norse mythology.

\section{Storytelling and Myth}

Most fauna and even some flora have the ability to communicate. Language is not a unique characteristic of our species and, according to the Cambridge Declaration of Consciousness, even conscience is probably not exclusive to humans (HARARI, 2017, p. 142). If there is one thing that separates us - Homo sapiens - from other species is the ability to tell stories through complex language. But even this ability was most definitely a characteristic of other hominids such as the extinct Homo neanderthalensis (D'ANASTASIO et al, 2013, p. 6) who had the articulatory apparatus for speech allowing them to create their own myths. 
Lévi-Strauss understood myth as a particular type of language, speech, linguistic phenomena, or system of communication (2001, p. 430).

The stories told by the campfire were mythical in scope: stories that tried to explain the sun, the moon and the stars, the water cycle, the seasons, the wind and the origin of Man. For tens of thousands of years, millions of storytellers spun their tales and enriched the human experience by giving them ideas, role models and worldviews. Brian W. Sturm, in his paper The Enchanted Imagination: Storytelling's Power to Entrance Listeners, said that when people listen to a story they experience a storylistening trance, an altered state of consciousness, and while the storyteller verbalizes the story the listener creates the "true" story in his mind, with the overlay of personal experiences and memories (1999, p. 2).

We as a species need our myths and our mythical thought just as we need the relatively new scientific thought. Lévi-Strauss said "the kind of logic which is used by mythical thought is as rigorous as that of modern science". For him, the "difference relies not in the quality of the intellectual process, but in the nature of the things to which it is applied" (2001, p. 444). Before the rise of science and scientific thought in the seventeenth century, science used to be explained by myth and superstition. The author Stanisław Herman Lem said that it's very difficult to understand how ancient technologies emerged and that "[s]uccessful technologies used to have myth or superstition as their "theoretical foundation": their application was either preceded by a magic ritual (...), or they themselves became a form of ritual" (2013, p. 11).

The definition of myth will never be satisfactorily complete. As societies' morals, dreams, and desires change so do myths evolve, ergo its definition changes. Nevertheless, a brief dictionary definition is presented here, before a longer one, bearing in mind a Frank Herbert's quote from Chapterhouse: Dune: "Many things we do naturally become difficult only when we try to make them intellectual subjects. It is possible to know so much about a subject that you become totally ignorant" (1985, p. 114).

In the Merriam-Webster dictionary online there are a few interesting definitions: myth is usually considered a traditional story that presents the worldview of a people, a set of beliefs, or natural phenomenon; myths can be told as parables and allegories or can be stories around something or someone, a public figure or a fictional one that embodies special 
ideals; the word myth has also come to signify something false (MYTH, def. 1-4). Mark Morford and Robert Lenardon reject the concept of falseness attributed to myth: "Myth in a sense is the highest reality; and the thoughtless dismissal of myth as untruth, fiction, or a lie is the most barren and misleading definition of all" (1977, p. 5).

After the succinct definition above, a more elaborate one is necessary. Lauri Honko, in his paper The Problem of Defining Myth, published in 1972, gave us an approach to the problem and a detailed definition of myth with the main goal of drawing attention to the complexity of the term (1972, p. 18). He enumerated three factors that are influential in the difficulty for a consensus in defining myth: demythologization; ancient definitions; and modern theories (1972, p. 8).

In demythologization, or the stripping of mythic elements, he considered three main types: 1) the eradication of the word myth but the retention of the story (terminological demythologization); 2) the total rejection of the stories (total and compensatory); 3) the conception of myths as symbols to be interpreted, and not to be taken literally (partial and interpretative) (1972, p. 8-9).

For the ancient definitions, Honko listed ten ways that illustrate the plethora of opinions: 1) the mythographic interpretation; 2) philosophical criticism; 3) the pre-scientific interpretation; 4) the allegorical explanation based on natural phenomena; 5) the allegorical explanation based on spiritual qualities; 6) the etymological interpretation; 7) the historical (comparative and derivative) interpretation; 8) the Euhemeristic interpretation; 9) the 'sociological' interpretation or the deceit of priests; 10) the psychological interpretation (1972, p. 10-12).

Because the concept of myth is in continuous revision by modern scholars, with overlapping theories and approaches from different angles, Honko compiled twelve methodologies to the problem of defining the term: 1) explain enigmatic phenomena (myth as source of cognitive categories); 2) artistic medium (myth as form of symbolic expression); 3) the human collective unconscious (myth as projection of the subconscious); 4) facing the problems of society, culture and nature (myth as worldview and as an integrating factor in man's adaptation to life); 5) morality and behavior (myth as charter of behavior); 6) religious values and rituals (myth as legitimation of social institutions); 7) social relevance of myths inside a culture (myth as a marker of social relevance); 8) a reflection of 
a culture's qualities (myth as a mirror of culture, social structure, etc.) 9) manipulation of historical facts (myth as a result of historical situations); 10) communication by different media (myth as religious communication); 11) narrative nature (myth as religious genre); 12) methods of research for language, content, and structure of myths (myth as medium for structure) (1972, p. 12-14).

But the author didn't just enumerate the different opinions, points of view, and problems in defining myth, both in ancient and modern times. He presented a personal theory he considered to be not too broad and not too narrow; the definition is descriptive and concise, and it was built on four criteria (form, content, function, and context). For Lauri Honko, myth is a story or a religious account that explains the origin of the world or presents the deeds of important role models providing patterns of behavior, values, and morality. The actions or behaviors are to be replicated by ritual ceremonies that defend the world order and preserve the values of a society. Honko also presented the common idea of myths as fictional stories and its relation to non-religious areas such as politics and economy (1972, p. 15-16).

\section{Speculative Fiction, Box Office, and Superheroes}

The definition of genre and the definition of the genres themselves is a controversial issue because there is no consensus on a system of shared elements for the diversity of story patterns that have been created for thousands of years (MCKEE, 1997, p. 79). The genres evolve to encompass the stories that are told. Jacques Derrida has hypothesized that "[e]very text participates in one or several genres, there is no genreless text; there is always a genre and genres, yet such participation never amounts to belonging" (65). The genres are fluid but their conventions and limitations can galvanize inspired storytellers who can avoid clichés and use the limitations to their advantage: it's called the Principle of Creative Limitation (MCKEE, 1997, p. 91). The genre system is not necessarily a bad thing when properly used.

The speculative fiction mega-genre embraces the genres of fantasy, horror, and science fiction, and all the subgenres and hybridizations the mentioned three can offer. The author Robert Heinlein coined speculative 
fiction in 1948 (SHIMKUS, 2012, p. 26) to refer to a subset of science fiction that was more social and people-oriented, in detriment of the gadget-oriented stories (HEINLEIN, 1991, p. 5). The Speculative Literature Foundation, launched in 2004, defined speculative fiction as a "catch-all term" that includes folk and fairy tales, fantasy, horror, magical realism, modern myth-making, science fiction, slipstream, etc. (SHIMKUS, 2012, p. 25). The evolution of the term is evident but that is not, by any means, a negative thing; it's part of the natural process of genre evolution.

For Orson Scott Card the speculative genres of fantasy and science fiction are the closest ones to the archetypes and myths that people crave for (1990, p. 16) and, in the author's opinion, writing fantasy is no less rigorous than science fiction and the latter has no less mythic traces than the first (1990, p. 21). Myths and legends endure time and have been frequently retold due to their ability to be reshaped; nowadays a new phenomenon has arisen and some myths are retold in futuristic contexts and settings with the goal of telling stories that resonate with the contemporary public (STEINKE, 2017, p. 19-20). Nick Redfern studied genre trends in the United States of America box office between 1991 and 2010 - the top fifty grossing films for each year - and concluded that the genres of fantasy and science fiction are monopolizing the market (2012, p. 1). The study has some controversial issues, including his genre classification and the decline in genre variety. The fact is that fantasy and science fiction are permeable to many other genres; therefore the thematic narrowing he advocated is not so evident.

The hegemony of the speculative fiction genre with its mythical elements is undeniable but these new myths are, in fact, the old myths made new by being tailored to a modern sensibility. John Boorman, director of the fantasy classic film Excalibur said it best:

I have a theory about a good story. We know it already, we've heard it a thousand times, but it holds us, we listen, we want to know what happens next. Why? I think we're hearing echoes of some deep pattern of early happenings in the human race that is now being repeated. Listen carefully to the echoes of myth. It has much more to tell us than the petty lies and insignificant truths of recorded history. (qtd. in Umland and Umland, 1996, p. 142)

Campbell's monomyth gives us the insight that we keep telling the 
same stories over and over again. The theory, based in Jung's archetypes and collective unconscious, is a basic structure that developed the formula of rites of passage - separation, initiation, return - and used it to describe and understand myths about heroes (RAt, 2016, p. 39) and other stories.

The notion of basic plots in drama and literature goes back at least to [Georges] Polti (1916), who outlined 36 "dramatic situations." Polti indicated that his list was based on one from Goethe, who in turn credited Carlo Gozzi (1720-1806). Booker (2006) held that these can be accommodated within his seven basic plots. (PHILLIPS, 2012, p. 154)

Jonathan Phillips came up with a slightly different number of plots to be used in scientific research. He recognizes that his list may be incomplete but he identified eight standard plots for the storytelling exercise of reporting and promoting scientific ideas. The eight basic plots are designed for scientists to improve their published work by using storytelling (2012, p. 153, 159-160), therefore, storytelling and mythical thinking are present in all human activities, even in the formal scientific explanation of new discoveries. The people who can harness its power will succeed in transmitting their ideas in a better way.

Table 1 aims to demonstrate the hegemony of the speculative fiction cinematic storytelling by showing the top one hundred grossing films of all time (ALL TIME BOX OFFICE MOJO). Two things are immediately evident: the fantasy and science fiction films produced in the U.S.A. dominate the market, and the superhero movies occupy a substantial proportion of the list. The grey-numbered cells are the films considered to be speculative fiction in this paper. The numbers are staggering. Over ninety percent of the movies are speculative fiction and the few that are not, some have fantasy or sci-fi elements. The darker cells are the superhero movies; they make twenty-seven percent of the list.

Liam Burke (qtd. in LABARRE, 2016) said that the current golden age of superhero movies is not to be explained by one single factor, be it political criticism, conglomerate strategies of franchising and merchandising, the new generation of directors interested in these narratives, and the increasing quality and decreasing costs in digital effects (2) that make possible to project into the silver screen the stories that have been confined to the printed page. One factor that is not being taken into count is 
the modern Man's craving for new myths, new mythic stories that are appropriate to our time and age, stories that present the proper role models to our modern mentality, and explore our fears and desires for the future.

The superhero narratives tend to convey strong role models with stout morals that will risk life and limb to save others - the paragon of altruism (e.g. Captain America). There is also the concept of the anti-hero, the cynical person with a heart of gold (e.g. Deadpool). Even well-written antagonists, who tend to be less flat and pure evil, are loved in modern stories (they are the heroes of their own stories, it's often said). Their internal conflict is presented in a more humane and realistic way in contemporary speculative fiction (e.g. Thanos). Thanos' morality in Avengers: Infinity War is questionable, to say the least - mass genocide is never the answer - but his mission to solve the over-population and finite resources problem is a real problem in the real world, one of several that must be addressed. The speculative fiction stories allow people to think about these problems in an operatic way through the "what if?" premise.

Table 1: All Time Box Office: Worldwide Grosses (accessed on 9 January 2019)

\begin{tabular}{|c|c|c|c|c|c|c|c|}
\hline 1 & Avatar & 26 & $\begin{array}{l}\text { Pirates of the } \\
\text { Caribbean: } \\
\text { Dead Man's } \\
\text { Chest }\end{array}$ & 51 & Shrek 2 & 76 & Coco \\
\hline 2 & Titanic & 27 & $\begin{array}{l}\text { Rogue One: } \\
\text { A Star Wars } \\
\text { Story }\end{array}$ & 52 & $\begin{array}{l}\text { Harry Potter } \\
\text { and the Go- } \\
\text { blet of Fire }\end{array}$ & 77 & $\begin{array}{l}\text { Shrek } \\
\text { Third }\end{array}$ \\
\hline 3 & $\begin{array}{l}\text { Star Wars: } \\
\text { The Force } \\
\text { Awakens }\end{array}$ & 28 & $\begin{array}{l}\text { Pirates of the } \\
\text { Caribbean: } \\
\text { On Stranger } \\
\text { Tides }\end{array}$ & 53 & Spider-Man 3 & 78 & $\begin{array}{l}\text { Harry Pot- } \\
\text { ter and the } \\
\text { Prisoner of } \\
\text { Azkaban }\end{array}$ \\
\hline 4 & $\begin{array}{l}\text { Avengers: } \\
\text { Infinity War }\end{array}$ & 29 & $\begin{array}{l}\text { Despicable } \\
\text { Me } 3\end{array}$ & 54 & $\begin{array}{l}\text { lce Age: } \\
\text { Dawn of the } \\
\text { Dinosaurs }\end{array}$ & 79 & $\begin{array}{l}\text { Pirates of the } \\
\text { Carib b ean: } \\
\text { Dead Men Tell } \\
\text { No Tales }\end{array}$ \\
\hline 5 & $\begin{array}{l}\text { Jur a s s i c } \\
\text { World }\end{array}$ & 30 & Jurassic Park & 55 & Spectre & 80 & $\begin{array}{l}\text { E.T.: The Ex- } \\
\text { tra-Terrestrial }\end{array}$ \\
\hline 6 & $\begin{array}{l}\text { The Aven- } \\
\text { gers }\end{array}$ & 31 & Finding Dory & 56 & $\begin{array}{l}\text { Spider-Man: } \\
\text { Homecoming }\end{array}$ & 81 & $\begin{array}{l}\text { Mission: Im- } \\
\text { possible } \\
\text { Fallout }\end{array}$ \\
\hline
\end{tabular}




\begin{tabular}{|c|c|c|c|c|c|c|c|}
\hline 7 & Furious 7 & 32 & $\begin{array}{l}\text { Star Wars: } \\
\text { Episode I - } \\
\text { The Phantom } \\
\text { Menace }\end{array}$ & 57 & $\begin{array}{l}\text { Harry Pot- } \\
\text { ter and the } \\
\text { Chamber of } \\
\text { Secrets }\end{array}$ & 82 & $\begin{array}{l}\text { Fast \& Fu- } \\
\text { rious } 6\end{array}$ \\
\hline 8 & $\begin{array}{l}\text { Avengers: } \\
\text { Age of Ul- } \\
\text { tron }\end{array}$ & 33 & $\begin{array}{l}\text { Alice in Won- } \\
\text { derland }\end{array}$ & 58 & $\begin{array}{l}\text { Ice Age: Con- } \\
\text { tinental Drift }\end{array}$ & 83 & $\begin{array}{l}\text { Indiana Jones } \\
\text { and the King- } \\
\text { dom of the } \\
\text { Crystal Skull }\end{array}$ \\
\hline 9 & $\begin{array}{l}\text { Black Pan- } \\
\text { ther }\end{array}$ & 34 & Zootopia & 59 & $\begin{array}{l}\text { The Secret } \\
\text { Life of Pets }\end{array}$ & 84 & Spider-Man 2 \\
\hline 10 & $\begin{array}{l}\text { Harry Po- } \\
\text { tter and } \\
\text { the Deathly } \\
\text { Hallows Part } \\
2\end{array}$ & 35 & $\begin{array}{l}\text { The Hobbit: } \\
\text { An Unexpec- } \\
\text { ted Journey }\end{array}$ & 60 & $\begin{array}{l}\text { Batman v } \\
\text { Superman: } \\
\text { Dawn of Jus- } \\
\text { tice }\end{array}$ & 85 & Deadpool \\
\hline 11 & $\begin{array}{l}\text { Star Wars: } \\
\text { The Last } \\
\text { Jedi }\end{array}$ & 36 & $\begin{array}{l}\text { The Dark Kni- } \\
\text { ght }\end{array}$ & 61 & $\begin{array}{l}\text { The Lord } \\
\text { of the Rin- } \\
\text { gs: The } \\
\text { Fellowship of } \\
\text { the Ring }\end{array}$ & 86 & Star Wars \\
\hline 12 & $\begin{array}{l}\text { J u r a s s i c } \\
\text { World: Fallen } \\
\text { Kingdom }\end{array}$ & 37 & $\begin{array}{l}\text { Harry Potter } \\
\text { and the Sor- } \\
\text { cerer's Stone }\end{array}$ & 62 & $\begin{array}{l}\text { Wolf Warrior } \\
2\end{array}$ & 87 & $\begin{array}{l}\text { Guardians of } \\
\text { the Galaxy }\end{array}$ \\
\hline 13 & Frozen & 38 & $\begin{array}{l}\text { Despicable } \\
\text { Me } 2\end{array}$ & 63 & $\begin{array}{l}\text { The Hunger } \\
\text { Games: Cat- } \\
\text { ching Fire }\end{array}$ & 88 & 2012 \\
\hline 14 & $\begin{array}{l}\text { Beauty and } \\
\text { the Beast }\end{array}$ & 39 & The Lion King & 64 & $\begin{array}{l}\text { Guardians of } \\
\text { the Galaxy } \\
\text { Vol. } 2\end{array}$ & 89 & Maleficient \\
\hline 15 & Incredibles 2 & 40 & $\begin{array}{l}\text { The Jungle } \\
\text { Book }\end{array}$ & 65 & Inside Out & 90 & $\begin{array}{l}\text { The Da Vinci } \\
\text { Code }\end{array}$ \\
\hline 16 & $\begin{array}{l}\text { The Fate of } \\
\text { the Furious }\end{array}$ & 41 & $\begin{array}{l}\text { Pirates of the } \\
\text { Caribbean: At } \\
\text { World's End }\end{array}$ & 66 & Venon & 91 & $\begin{array}{l}\text { The Amazing } \\
\text { Spider-Man }\end{array}$ \\
\hline 17 & Iron Man 3 & 42 & $\begin{array}{l}\text { Jumanji: Wel- } \\
\text { come to the } \\
\text { Jungle }\end{array}$ & 67 & $\begin{array}{l}\text { Thor: Ragna- } \\
\text { rok }\end{array}$ & 92 & $\begin{array}{l}\text { The Hun- } \\
\text { ger Games: } \\
\text { Mockingjay - } \\
\text { Part 1 }\end{array}$ \\
\hline 18 & Minions & 43 & $\begin{array}{l}\text { Harry Potter } \\
\text { and the Dea- } \\
\text { thly Hallows } \\
\text { Part } 1\end{array}$ & 68 & $\begin{array}{l}\text { Star Wars: } \\
\text { Episode III - } \\
\text { Revenge of } \\
\text { the Sith }\end{array}$ & 93 & $\begin{array}{l}\text { Shrek Forever } \\
\text { After }\end{array}$ \\
\hline
\end{tabular}




\begin{tabular}{|c|c|c|c|c|c|c|c|}
\hline 19 & $\begin{array}{l}\text { C a p t a i n } \\
\text { America: Ci- } \\
\text { vil War }\end{array}$ & 44 & $\begin{array}{l}\text { The Hobbit: } \\
\text { The Desola- } \\
\text { tion of Smaug }\end{array}$ & 69 & $\begin{array}{l}\text { Transfor- } \\
\text { mers: Re- } \\
\text { venge of the } \\
\text { Fallen }\end{array}$ & 94 & $\begin{array}{l}\text { X-Men: Days } \\
\text { of Future Past }\end{array}$ \\
\hline 20 & $\begin{array}{l}\text { Transfor- } \\
\text { mers: Dark } \\
\text { of the Moon }\end{array}$ & 45 & $\begin{array}{l}\text { The Hobbit: } \\
\text { The Battle of } \\
\text { the Five Ar- } \\
\text { mies }\end{array}$ & 70 & $\begin{array}{l}\text { The Twili- } \\
\text { ght Saga: } \\
\text { B re a k i n g } \\
\text { Dawn Part } 2\end{array}$ & 95 & $\begin{array}{l}\text { Madagascar } \\
\text { 3: Europe's } \\
\text { Most Wanted }\end{array}$ \\
\hline 21 & $\begin{array}{l}\text { The Lord of } \\
\text { the Rings: } \\
\text { The Return } \\
\text { of the King }\end{array}$ & 46 & Aquaman & 71 & Inception & 96 & $\begin{array}{l}\text { S u i c i d e } \\
\text { Squad }\end{array}$ \\
\hline 22 & Skyfall & 47 & Finding Nemo & 72 & $\begin{array}{l}\text { Wonder Wo- } \\
\text { man }\end{array}$ & 97 & $\begin{array}{l}\text { The Chroni- } \\
\text { cles of Nar- } \\
\text { nia: The Lion, } \\
\text { the Witch and } \\
\text { the Wardrobe }\end{array}$ \\
\hline 23 & $\begin{array}{l}\text { Transfor- } \\
\text { mers: Age of } \\
\text { Extinction }\end{array}$ & 48 & $\begin{array}{l}\text { Harry Potter } \\
\text { and the Order } \\
\text { of the Phoenix }\end{array}$ & 73 & Spider-Man & 98 & $\begin{array}{l}\text { Monsters } \\
\text { University }\end{array}$ \\
\hline 24 & $\begin{array}{l}\text { The Dark } \\
\text { Knight Rises }\end{array}$ & 49 & $\begin{array}{l}\text { Harry Potter } \\
\text { and the Half- } \\
\text {-Blood Prince }\end{array}$ & 74 & $\begin{array}{l}\text { Independen- } \\
\text { ce Day }\end{array}$ & 99 & $\begin{array}{l}\text { B o hemian } \\
\text { Rhapsody }\end{array}$ \\
\hline 25 & Toy Story 3 & 50 & $\begin{array}{l}\text { The Lord } \\
\text { of the Rin- } \\
\text { gs: The Two } \\
\text { Towers }\end{array}$ & 75 & $\begin{array}{l}\text { Fant a stic } \\
\text { Beasts and } \\
\text { Where To } \\
\text { Find Them }\end{array}$ & 100 & Deadpool 2 \\
\hline
\end{tabular}

Umberto Eco said that the superhero stories are static, immobile, maintaining the illusion of an ever-continuing present. This maintenance of the superhero immortality, breaking the natural flow of time from one story to another, is necessary from the mythopoeic and commercial point of view (1972, p. 19). Eco points out that the people's hunger for redundancy and repetition is very much present in popular narratives (1972, p. 21). People look for familiar stories and favorite characters; it comforts them. The staticity of the stories arises as the result of denying the superheroes a normal life: to marry, have children, and die. Nowadays, this problem is being addressed more often: superheroes are having big narrative arches; there is a new wave of artists with new ideas; the big companies (DC and Marvel) created alternate realities and timelines for 
well-known characters, which the public enjoys and increases the revenue. The examples are many but only ten will be mentioned here to illustrate the idea: $V$ for Vendetta (1982-89); Watchmen (1986-87); The Dark Knight Returns (1986); Kingdom Come (1996); Loki (2004); The Umbrella Academy (2007-08); Wolverine: Old Man Logan (2008-09); Jupiter's Legacy (2013-); Starlight (2014); The Vision (2015-).

There are various reasons to explain the phenomenon of less staticity in contemporary superhero stories. This paper will present five reasons: 1) the maturation of the medium through its artists/publishers and the area of Comics Studies (e.g. Will Eisner and Scott McCloud); 2) the public's necessity to consume "complete" and more mature stories; 3) the introduction of the graphic novel as the new quality paradigm in graphic literature - stories in book format with a beginning, middle, and end; 4) the well-planned story arches from the big companies and their multiverses that permit artists to work on several timelines and alternate realities; 5) the publication of narratives on the Internet - digital comics and webcomics created outside publisher's rules, where the authors have more creative liberty.

In all genres, but more often in speculative fiction, one can find the symbolic images and narrative abbreviations of archetypes. Archetypes are present in all stories, but the speculative fiction genre has a propensity to myth and dream-like narratives that make them fertile ground for these universal symbols. Christopher Vogler pondered on several archetypes that have been adapted from myths, fairy tales and dreams into cinema. These archetypes are recurring character types such as the questing hero, the herald, the wise old man/woman (the mentor), the threshold guardians, the shapeshifter, the shadowy antagonist, the trickster, and the allies (2007, p. 23, 26). Vogler also presented the possibility of these archetypal patterns working in a non-static way; the archetypes as functions permit the flexible and temporary attribution of a specific archetype to a character; one character can be several archetypes, transitioning from one to another as if changing masks. The archetypes as characteristics of the protagonist give the hero the possibility to alter archetypical masks giving him, or her, more depth (2007, p. 24-25).

Carl Jung coined the concept of archetypes and gave these mythological patterns signification (LÉVI-STRAUSS, 2001, p. 429). These images, or symbols, are narrative abbreviations in a story or situation. Jung 
considered that the first archetype, "discovered" by Freud, was the one that characterizes Oedipus. The Oedipal incest complex and many others help explain how the human mind works (MORFORD and LENARDON, 1977, p. 7-9). Myth and archetypes are inextricably connected because of their universal qualities.

Michael Faber and John Mayer (qtd. in KIDD, 2016, p. 26) attributed certain characteristics to the modern archetypes: they are characters in a story; they are represented as mental models; they provoke emotional responses; they work at an unconscious level; and they are memorable and easy to learn: the reason why they endure time.

Stereotypes, on the other hand, "(...) are very culture specific. In many cultures, certain groups are seen as possessing specific, often negative, characteristics. Individuals within those groups are treated as if these negative stereotypes are true, which is seldom the case". Stereotypes are natural phenomena but, unlike archetypes, they can be a problem to the contemporary multi-cultural societies when they are overused or used unethically (KIDD, 2016, p. 26-28).

The new cinematic myths can be used to break old notions of gender and race: in Black Panther (2018), we have a black superhero, protected by female warriors, brother to a bright young woman - the top scientist in Wakanda, the most advanced country in the world, governed by Africans. This movie, positioned in ninth place in the list of the top grossing films worldwide, was a public and critics success (the first superhero movie nominated for best picture at the Oscars); the powerful and technological African nation image the movie conveyed is having its beneficial repercussions in black communities all over the world. The way Wakanda is presented is appropriate for the contemporary public: a magnificent and positive amalgamation of the old and the new. Movies like Black Panther and Wonder Woman (2017) are paramount because they offer diversity and originality back to the world and they break negative stereotypes in popular culture.

\section{Are the New Myths an American Thing?}

In Table 1 all films are American productions, or co-productions, for the exception of Wolf Warrior 2 (2016), which is the number one 
top-grossing Chinese film of all time. It could be argued that the speculative fiction genre and superhero films are an American trend that is monopolizing cinematic culture all over the world. The lack of production of these genre films in other countries is conveyed by Table 2, which presents the top-grossing foreign language films in the world box office, since 1980 (FOREIGN LANGUAGE).

According to Table 2, only fourteen films of the top 100 are considered speculative fiction (grey-numbered cells) on this paper. The superhero movies fall from twenty-seven percent, in the previous table, to one percent in Table 2. Reading both tables it's arguable that the speculative fiction genre hegemony is a world phenomenon with its epicenter in the U.S.A.

Table 2: Box Office Mojo: Foreign Language (accessed on 9 January 2019)

\begin{tabular}{|c|c|c|c|c|c|c|c|}
\hline 1 & $\begin{array}{l}\text { Crouching } \\
\text { Tiger, Hidden } \\
\text { Dragon }\end{array}$ & 26 & $\begin{array}{l}\text { Brotherhood } \\
\text { of the Wolf }\end{array}$ & 51 & Amour & 76 & $\begin{array}{l}\text { Amores Per- } \\
\text { ros }\end{array}$ \\
\hline 2 & $\begin{array}{l}\text { Life is Beau- } \\
\text { tiful }\end{array}$ & 27 & Spirited Away & 52 & $\begin{array}{l}\text { The Closet } \\
\text { (Le Placard) }\end{array}$ & 77 & $\begin{array}{l}\text { Bread anc } \\
\text { Tulips }\end{array}$ \\
\hline 3 & Hero & 28 & $\begin{array}{lr}\begin{array}{l}\text { House } \\
\text { Flying }\end{array} & \text { Dag- } \\
\text { gers } & \\
\end{array}$ & 53 & $\begin{array}{l}\text { The Grand- } \\
\text { master }\end{array}$ & 78 & $\begin{array}{l}\text { Chennai Ex- } \\
\text { press }\end{array}$ \\
\hline 4 & $\begin{array}{l}\text { Instructions } \\
\text { Not Included }\end{array}$ & 29 & P.K. & 54 & $\begin{array}{l}\text { Curse of } \\
\text { the Golden } \\
\text { Flower }\end{array}$ & 79 & $\begin{array}{l}\text { Farewell My } \\
\text { Concubine }\end{array}$ \\
\hline 5 & $\begin{array}{l}\text { Pan's La- } \\
\text { byrinth }\end{array}$ & 30 & $\begin{array}{l}\text { La Vie en } \\
\text { Rose }\end{array}$ & 55 & 3 Idiots & 80 & $\begin{array}{l}\text { Bad Educa- } \\
\text { tion }\end{array}$ \\
\hline 6 & Amélie & 31 & $\begin{array}{l}\text { The Intoucha- } \\
\text { bles }\end{array}$ & 56 & $\begin{array}{l}\text { Maria Full of } \\
\text { Grace }\end{array}$ & 81 & $\begin{array}{l}\text { The Gir } \\
\text { Who Kicked } \\
\text { the Hornet's } \\
\text { Nest }\end{array}$ \\
\hline 7 & $\begin{array}{l}\text { Jet Li's Fear- } \\
\text { less }\end{array}$ & 32 & $\begin{array}{l}\text { The Girl with } \\
\text { the Dragon } \\
\text { Tattoo }\end{array}$ & 57 & $\begin{array}{l}\text { A Very Long } \\
\text { Engagement }\end{array}$ & 82 & Biutiful \\
\hline 8 & || Postino & 33 & $\begin{array}{l}\text { Shall We Dan- } \\
\text { ce? }\end{array}$ & 58 & $\begin{array}{l}\text { The Secret in } \\
\text { Their Eyes }\end{array}$ & 83 & $\begin{array}{l}\text { La Femme } \\
\text { Nikita }\end{array}$ \\
\hline 9 & $\begin{array}{l}\text { Like Water } \\
\text { for Chocolate }\end{array}$ & 34 & Talk to Her & 59 & Cantinflas & 84 & Your Name. \\
\hline
\end{tabular}




\begin{tabular}{|c|c|c|c|c|c|c|c|}
\hline 10 & $\begin{array}{l}\text { La Cage aux } \\
\text { Folles }\end{array}$ & 35 & $\begin{array}{l}\text { Un Gallo con } \\
\text { Muchos Hue- } \\
\text { vos }\end{array}$ & 60 & Sultan & 85 & $\begin{array}{l}\text { Broken Em- } \\
\text { braces }\end{array}$ \\
\hline 11 & $\begin{array}{l}\text { Baahubali 2: } \\
\text { The Conclu- } \\
\text { sion }\end{array}$ & 36 & $\begin{array}{l}\text { My Life as a } \\
\text { Dog }\end{array}$ & & $\begin{array}{l}\text { Nowhere in } \\
\text { Africa }\end{array}$ & 86 & I am Love \\
\hline 12 & $\begin{array}{ll}\text { Kung } & \text { Fu } \\
\text { Hustle } & \end{array}$ & 37 & $\begin{array}{l}\text { All About My } \\
\text { Mother }\end{array}$ & 62 & Tell No One & 87 & $\begin{array}{l}\text { Jean de Flo- } \\
\text { rette }\end{array}$ \\
\hline 13 & $\begin{array}{l}\text { The Motorcy- } \\
\text { cle Diaries }\end{array}$ & 38 & Dhoom 3 & & $\begin{array}{l}\text { Coco Before } \\
\text { Chanel }\end{array}$ & 88 & $\begin{array}{l}\text { Lust, Cau- } \\
\text { tion }\end{array}$ \\
\hline 14 & Iron Monkey & 39 & Sanju & 64 & $\begin{array}{l}\text { Cyrano de } \\
\text { Bergerac }\end{array}$ & 89 & $\begin{array}{l}\text { Ong Bak: } \\
\text { The Thai } \\
\text { Warrior }\end{array}$ \\
\hline 15 & $\begin{array}{l}\text { M o n s o o n } \\
\text { Wedding }\end{array}$ & 40 & Sarah's Key & 65 & Kolya & 90 & $\begin{array}{l}\text { Italian for } \\
\text { Beginners }\end{array}$ \\
\hline 16 & $\begin{array}{l}\text { Y Tu Mama } \\
\text { Tambien }\end{array}$ & & $\begin{array}{l}\text { The Girl Who } \\
\text { Played with } \\
\text { Fire }\end{array}$ & 66 & $\begin{array}{l}\text { El Crimen del } \\
\text { Padre Amaro }\end{array}$ & 91 & $\begin{array}{l}\text { Au Revoir, } \\
\text { Les Enfants }\end{array}$ \\
\hline 17 & Volver & 42 & City of God & 67 & Mongol & 92 & $\begin{array}{l}\text { Mediterra- } \\
\text { neo }\end{array}$ \\
\hline 18 & $\begin{array}{l}\text { Under the } \\
\text { Same Moon }\end{array}$ & 43 & $\begin{array}{l}\text { Eat Drink Man } \\
\text { Woman }\end{array}$ & 68 & Indochine & 93 & $\begin{array}{l}\text { Babette's } \\
\text { Feast }\end{array}$ \\
\hline 19 & $\begin{array}{l}\text { Cinema } \mathrm{Pa}- \\
\text { radiso }\end{array}$ & 44 & Run Lola Run & 69 & $\begin{array}{l}\text { Central Sta- } \\
\text { tion }\end{array}$ & 94 & Black Book \\
\hline 20 & Dangai & 45 & $\begin{array}{l}\text { Women on } \\
\text { the Verge of } \\
\text { a Nervous } \\
\text { Breakdown }\end{array}$ & 70 & $\begin{array}{l}\text { Europa, Eu- } \\
\text { ropa }\end{array}$ & 95 & $\begin{array}{l}\text { Ae Dil Hai } \\
\text { Mushkil }\end{array}$ \\
\hline 21 & $\begin{array}{l}\text { The Protec- } \\
\text { tor }\end{array}$ & 46 & $\begin{array}{l}\text { The Orphana- } \\
\text { ge }\end{array}$ & 71 & $\begin{array}{l}\text { Tiger Zinda } \\
\text { Hai }\end{array}$ & 96 & $\begin{array}{l}\text { The Lun- } \\
\text { chbox }\end{array}$ \\
\hline 22 & Padmaavat & 47 & A Separation & 72 & Water & 97 & $\begin{array}{l}\text { Antonia's } \\
\text { Line }\end{array}$ \\
\hline 23 & $\begin{array}{l}\text { No Manches } \\
\text { Frida }\end{array}$ & 48 & $\begin{array}{l}\text { La Cage aux } \\
\text { Folles } 2\end{array}$ & 73 & Downfall & 98 & Ya Veremos \\
\hline 24 & Das Boot & 49 & $\begin{array}{l}\text { The Wedding } \\
\text { Banquet }\end{array}$ & 74 & $\begin{array}{l}\text { The Counter- } \\
\text { feiters }\end{array}$ & 99 & $\begin{array}{l}\text { Mostly Mar- } \\
\text { tha }\end{array}$ \\
\hline 25 & $\begin{array}{l}\text { The Lives of } \\
\text { Others }\end{array}$ & 50 & $\begin{array}{l}\text { Fanny and } \\
\text { Alexander }\end{array}$ & 75 & Belle Epoque & 100 & 2.0 \\
\hline
\end{tabular}

Livio Bioglio and Ruggero Pensa understood the limitations of evaluating a film's success by the box office revenues and critics' reviews. For 
them, the most interesting alternative technique is related to the number of citations a movie receives from others produced a posteriori - what they called the network of citations (2018, p.2). Through complex algorithms and other techniques, they researched almost fifty thousand films in the Internet Movie Database and created a list with the twenty most influential films (Table 3). Twelve titles are considered speculative fiction in this paper: a noticeable number that allows the assumption that it's not just the top-grossing films that show the importance of the speculative fiction genre.

\section{Table 3: Most Influential Films}

\begin{tabular}{|c|c|c|c|c|c|c|c|}
\hline 1 & $\begin{array}{l}\text { The Wizard } \\
\text { of } \mathrm{Oz}\end{array}$ & 6 & Metropolis & 11 & Casablanca & 16 & $\begin{array}{l}\text { The Sear- } \\
\text { chers }\end{array}$ \\
\hline 2 & Star Wars & 7 & Citizen Kane & 12 & Dracula & 17 & Cabiria \\
\hline 3 & Psycho & 8 & $\begin{array}{l}\text { The Birth of a } \\
\text { Nation }\end{array}$ & 13 & The Godfather & 18 & $\begin{array}{l}\text { Dr. Strange- } \\
\text { love or: How } \\
\text { I Learned to } \\
\text { Stop Wor- } \\
\text { rying and } \\
\text { Love the } \\
\text { Bomb }\end{array}$ \\
\hline 4 & King Kong & 9 & Frankenstein & 14 & Jaws & 19 & $\begin{array}{l}\text { Gone With } \\
\text { the Wind }\end{array}$ \\
\hline 5 & $\begin{array}{l}\text { 2001: } \quad A \\
\text { S p a c e } \\
\text { Odyssey }\end{array}$ & 10 & $\begin{array}{l}\text { Snow White } \\
\text { and the Seven } \\
\text { Dwarfs }\end{array}$ & 15 & $\begin{array}{l}\text { Nosferatu, eine } \\
\text { Sy m p h o n i e } \\
\text { des Grauens }\end{array}$ & 20 & $\begin{array}{l}\text { Battleship } \\
\text { Potemkin }\end{array}$ \\
\hline
\end{tabular}

\section{Conclusions}

Many myths are lost or have lost their ability to resonate with the modern public. But the cinematic speculative fiction genre, through the creation and adaptation of myths and mythical stories, is bringing back the appropriate narratives filled with magic, wonder, role models, and the morals and tools we need for this age and time. The decline of myth and mythical thought seems to be receding because of the entertainment business and film production. To measure the human craving for mythical stories the box office revenues offer insight about the worldwide 
moviegoers' choices (Table 1). The list of the most influential films (Table 3) confirms the desire to see these types of stories in a medium - cinema - that was officially born in 1895.

Myth and mythical thought were once helpful to explain the unexplainable, such as the strange natural phenomena our ancestors couldn't comprehend. Later, the myth was useful in explaining the way our mind works and how dreams affect us as human beings. The world is getting more and more complex, and people are dependent on scientific knowledge and gadgets they don't fully understand. Mythical thought and scientific thought have similar characteristics and, despite the inherent differences, they can be woven together for a better and healthier perception of the world. The complexity and intricacy of the modern world are, sometimes, unexplainable and inscrutable to most people as well as the future of our world. The speculative fiction genre can treat complex subjects in an approachable way; therefore the new myths help us understand whom we are and where we can go from here. Myth and mythical thought are necessary to better deal with the complexity of our modern world and the future of our species.

\section{REFERENCES}

ALL TIME BOX OFFICE. Worldwide Grosses, Box Office Mojo. Available on: www.boxofficemojo.com/ alltime/world. Access on: 9 Jan. 2019.

BERNSTEIN, Paula. The 3 Rules of Transmedia Storytelling from Transmedia Guru Jeff Gomez. Indiewire, 3 Dec. 2013, Available on: www.indiewire.com/article/the-3-rules-of-transmedia-storytelling-from-transmedia-guru-jeff-gomez. Access on: 9 Jan. 2019.

BIOGLIO, Livio; PENSA, Ruggero. Identification of key films and personalities in the history of cinema from a Western perspective. Applied Network Science, ANS, 3.50, 2018. p. 1-23.

CAMPBELL, Joseph. The Hero with a Thousand Faces. New Jersey: Princeton University Press, 2004.

CAMPBELL, Joseph, et al. The Power of Myth. New York: Anchor Books, 1991.

CARD, Orson Scott. How to Write Science Fiction and Fantasy. Cincinnati: Writer's Digest Books, 1990.

D'ANASTASIO, Ruggero, et al. Micro-Biomechanics of the Kebara 2 Hyoid and Its Implications for Speech in Neanderthals. PLoS ONE, 8.12, 2013. p. 1-7.

DERRIDA, Jacques. The Law of Genre. Critical Inquiry, 7.1, 1980. p. 55-81.

ECO, Umberto. The Myth of Superman. Diacritics, 2.1, 1972. p. 14-22.

FOREIGN LANGUAGE. Box Office Mojo. Available on: www.boxofficemojo.com/genres/chart/?id=foreign.htm. Access on: 9 Jan. 2019. 
HAFÇI, Büşra; ASLITÜRK, Gül. Superheroes: Myths of Modern Age? Idil - Journal of Art and Language, IDIL, 6.30, 2017. p. 497-510.

HARARI, Yuval Noah. Homo Deus: A Brief History of Tomorrow. New York: HarperCollins, 2017.

HEINLEIN, Robert. On the Writing of Speculative Fiction. In: DOZOIS, Gardner et al (Org.) Writing Science Fiction \& Fantasy. Worcester: Davis Publications, 1991. p. 5-10.

HERBERT, Frank. Chapterhouse: Dune. New York: G.P. Putnam's Son, 1985.

HONKO, Lauri. The problem of defining myth. Scripta Instituti Donneriani Aboensis. 6, 1972. p. 20-30.

JENKINS, Henry. Convergence Culture: Where Old and New Media Collide. New York: New York University Press, 2006.

KIDD, Mary Anna. Archetypes, Stereotypes and Media Representation in a Multi-Cultural Society. Procedia - Social and Behavioral Sciences, PSBS, 236, 2016, p. 25-28.

LABARRE, Nicolas. Liam Burke, The Comic Book Film Adaptation: Exploring Modern Hollywood's Leading Genre // Drew Morton, Panel to the Screen: Style, American Film, and Comic Books During the Blockbuster Era. Transatlantica, 2, 2016.

LEM, Stanisław Herman. Summa Tecnologiae. Translated by Joanna Zylinska, Minnesota: University of Minnesota Press, 2013.

LÉVI-STRAUSS, Claude. The Structural Study of Myth. The Journal of American Folklore, TJAF, $68.68,270,1955$. p. 428-444.

Myth and Meaning. Routledge Classics, 2001.

MCKEE, Robert. Story: Substance, Structure, Style and the Principles of Screenwriting. London: Methuen, 1997.

MORFORD, Mark; LENARDON, Robert. Classical Mythology. London: Longman, 1977.

MYTH. Merriam-Webster. Available on: www.merriam-webster.com/dictionary/myth. Access on: 9 Jan. 2019.

PHILLIPS, Jonathan. Storytelling in Earth Sciences: The Eight Basic Plots. Earth-Science Reviews, ESR, 115.3, 2012. p. 153-162.

RATĀ, Irina. "Only Gods are Real”: The Mythopoeic Dimension of Neil Gaiman's American Gods. Romanian Journal of English Studies, RJES, 13.1, 2016. p. 35-44.

REDFERN, Nick. Genre trends at the US box office, 1991 to 2010. European Journal of American Culture, EJAC, 31.2, 2012. p. 145-167.

SHIMKUS, James. Teaching Speculative Fiction in College: A Pedagogy for Making English Studies Relevant. 2012. Dissertation (Ph.D.) - Georgia State University. Available on: http://scholarworks.gsu. edu/english_diss/95. Access on: 9 Jan. 2019.

STEINKE, Gabriela. To boldly go: futuristic retelling of ancient Welsh myths. In: SERRAS, Adelaide et al (Orgs.), Messengers from the Stars: On Science Fiction and Fantasy $\mathbf{N}^{\mathbf{0}} \mathbf{2}$. Lisbon: University of Lisbon Centre for English Studies, 2017, p. 10-20.

STURM, Brian. The Enchanted Imagination: Storytelling's Power to Entrance Listeners. School Library Media Research, SLMR, 2, 1999. p. 1-21.

UMLAND, Rebecca; UMLAND, Samuel. The use of Arthurian legend in Hollywood film: from Connec- 
ticut Yankees to Fisher King. Connecticut: Greenwood Press, 1996.

VOGLER, Christopher. The Writer's Journey: Mythic Structure for Storytellers and Screenwriters. San Francisco: Michael Wiese Productions, 2007.

Data do recebimento: 30 julho 2019

Data da aprovação: 04 novembro 2019 


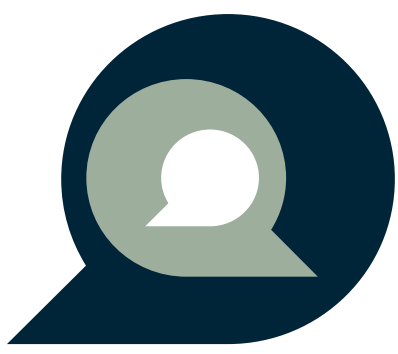

